\title{
A Polymeric Adsorbent for Removal And Recovery of Nickel From Aqueous Media
}

\author{
Sulu Ortamdan Nikelin Uzaklaştırılması ve Geri Kazanımı Için Polimerik \\ Bir Adsorban \\ Berna Saraçoğlu Kaya ${ }^{\circledR}$ and Hülya Güler ${ }^{\oplus}$ \\ Department of Chemical Engineering, Sivas Cumhuriyet University, Sivas, Turkey.
}

\section{A B STRACT}

\begin{abstract}
The Interpenetrating Polymer Network (IPN) structure was obtained by gamma radiation of solution of polyethylene glycol (PEG) (35000MW) in an acrylonitrile (AN) to 14 and 60kGy doses were amidoximated with hydroxylamine solution at optimum amidoximation conditions. Effects of $\mathrm{pH}(2-10)$ and $\mathrm{mNi} / \mathrm{mIPN}$ ratio $(0.002-0.5)$ in $\mathrm{Ni}^{2+}$ adsorption were examined by batch process and optimum values were determined as 8 and 0.4 for both doses, respectively. Also, the effect of flow rate to $\mathrm{Ni}^{2+}$ adsorption was examined by the reflux flow process with a fixed-bed reactor at room temperature. Optimum flow rate is determined as $6 \mathrm{~mL} / \mathrm{s}$ at optimum $\mathrm{pH}$. $\mathrm{Ni}^{2+}$ adsorption studies were carried out in batch $(\mathrm{pH}=6$ and 8$)$ and flow $(\mathrm{pH}=$ 8) systems. Maximum adsorption values reached for irradiated to 14 and $60 \mathrm{kGy}$ doses and amidoximated IPNs were given as 105 and $99 \mathrm{mgNi} / \mathrm{gIPN}$ in batch system (pH=6), 378 and $361 \mathrm{mgNi} / \mathrm{gIPN}$ in batch system $(\mathrm{pH}=8)$ and 891 and $673 \mathrm{mgNi} / \mathrm{gIPN}$ in flow system $(\mathrm{pH}=8)$, respectively. Maximum elution efficiency was obtained for $\mathrm{HCl}$ as being $99.5 \%$ and $66.1 \%$ for IPNs irradiated to 14 and 60kGy doses and amidoximated, respectively. FTIR results showed that $\mathrm{HCl}$ caused structural deformation. Minimum elution efficiency was obtained for $\left(\mathrm{NH}_{4}\right)_{2} \mathrm{CO}_{3}$ as being $60.1 \%$ and $58.2 \%$ for IPNs irradiated to 14 and $60 \mathrm{kGy}$, respectively, by the minimum deformation.
\end{abstract}

\section{Key Words}

IPN, nickel, adsorption, elution.

\section{öz}

\begin{abstract}
| çiçe-geçmiş Polimer Ağı (IPN) yapı, polietilen glikol (PEG) (35000MW) çözeltisinin akrilonitril (AN) içerisinde 14 ve 60 kGy dozlarına gama ışınımıyla elde edilmiş ve optimum amidoximasyon koşullarında hidroksilamin çözeltisi ile amidoksimleştirilmiştir. $\mathrm{Ni}^{2+}$ adsorpsiyonunda $\mathrm{pH}$ (2-10) ve $\mathrm{mNi} / \mathrm{mIPN}$ oranının (0.01-0.5) etkisi kesikli sistemde incelenmiş ve her iki doz için sırasıyla en uygun değer 8 ve 0.4 olarak belirlenmiştir. Ayrıca, akış hızının Ni²+ adsorpsiyonuna etkisi sabit yataklı bir reaktör ile geri akışlı sistemde oda sıcaklığında incelenmiştir. En uygun akış hızı, en uygun $\mathrm{pH}^{\prime} \mathrm{da} 6 \mathrm{~mL} / \mathrm{dk}$ olarak belirlenmiştir. $\mathrm{Ni}^{2+}$ adsorpsiyon çalışmaları, kesikli ( $\mathrm{pH}=6$ ve 8) ve akışlı $(\mathrm{pH}=8)$ sistemde gerçekleştirilmiştir. 14 ve $60 \mathrm{kGy}$ dozlarına ışınlanmış ve amidoksimleştirilmiş IPN'lerin en yüksek adsorpsiyon değerleri sırasıyla, kesikli sisteminde, pH= 6 için 105 ve 99 mgNi/gIPN pH= 8 için 378 ve 361 mgNi/gIPN, akışlı sistemde; pH= 8 için 891 ve 673 mgNi/gIPN olarak saptanmıştır. En yüksek elüsyon verimi, 14 ve 60kGy dozlarına ışınlanmış ve amidoksimleştirilmiş IPN'ler için sırasıyla \%99.5 ve \%66.1 olarak HCl ile elde edilmiştir. FTIR sonuçları, HCl'nin yapısal deformasyona neden olduğunu göstermiştir. En düşük deformasyonla 14 ve $60 \mathrm{kGy}$ 'ye ışınlanan IPN'ler için elüsyon verimi \%60.1 ve \%58.2 olarak $\left(\mathrm{NH}_{4}\right)_{2} \mathrm{CO}_{3}$ ile elde edilmiştir.
\end{abstract}

\section{Anahtar Kelimeler}

IPN, nikel, adsorpsiyon, elüsyon.

Article History: Received: Sep 17, 2019; Revised: Oct 27, 2019; Accepted: Jan, 2020; Available Online: Apr 1, 2020 DOI: https://doi.org/10.15671/hjbc.634459

Correspondence to: B. Saraçoğlu Kaya, Department of Chemical Engineering, Sivas Cumhuriyet University, Sivas, Turkey.

E-Mail: berna@cumhuriyet.edu.tr 


\section{INTRODUCTION}

bee he he presence of nickel ions in the aqueous media has been of great concern because of its toxic nature, binds to nucleic acids and causes mutation. In spite of this property, nickel is a heavy metal that must be recovery due to its technological importance. Researchers improved so many adsorbent based on organic [1-14], inorganic [15-18] and biologic [19-21] for adsorption process. Required parameters for the improved adsorbent are selective for metal ions, the ability for low concentration adsorption, high adsorption capacity, regenerable and economic [1]. Researches are direct to novel polymeric adsorbents with ion exchange or/and chelating resin to obtain all these parameters. Polyacrylamidoxime resins are determined as a feasible adsorbent for the removal and recovery of metal ions from aqueous media because of high adsorption capacity and ability to regeneration [1-21].

Both the amidoxime group and hydrophilic group contained adsorbents cover more metal ions than only amidoxime group contained. Because of this, among amidoxime, amide, carboxyl and hydroxyl groups, the amidoxime group is least hydrophilic. In adsorption, aqueous solution diffusion that is rate determined step is faster to the more hydrophilic polymer. In this respect adsorption increases according to the type and amount of hydrophilic group [1-3,5,7-10].

In this study, a new polymeric adsorbent bearing both hydrophilic groups and amidoxime groups synthesized as IPNs based on polyethylene glycol(PEG) and acrylonitrile(AN) which is developed to remove low concentrations of heavy metals in aqueous media. The IPNs which were developed for removal and recovery of low concentrations of uranium [1] from aqueous media were used for the same purpose for $\mathrm{Ni}^{2+}$ ions at two different radiation doses.

\section{MATERIALS and METHODS}

\section{Materials}

In this study for preparation of IPNs poly(ethylene glycol)(PEG, 35000MW) $\left(\mathrm{H}\left(\mathrm{OCH}_{2} \mathrm{CH}_{2}\right)_{n} \mathrm{OH}\right)$ (Merck), acrylonitrile(AN) $\quad\left(\mathrm{H}_{2} \mathrm{C}=\mathrm{CHCN}\right) \quad$ (Merck) and $\mathrm{N}, \mathrm{N}$ dimethylformamide (DMF) $\left(\mathrm{HCON}\left(\mathrm{CH}_{3}\right)_{2}\right)$ (Merck) were used at high purity. For amidoximation of IPNs, sodium hydroxide $(\mathrm{NaOH})$ (Merck) and hydroxylamine hydrochloride hexahydrate $\left(\mathrm{NH}_{2} \mathrm{OH} . \mathrm{HCl} .6 \mathrm{H}_{2} \mathrm{O}\right)$ (Aldrich) were used. For adsorption experiments, nickel solutions were prepared by dissolving appropriate amounts of nickel (II) nitrate hexahydrate $\left(\mathrm{Ni}\left(\mathrm{NO}_{3}\right)_{2} \cdot 6 \mathrm{H}_{2} \mathrm{O}\right)(\mathrm{BDH})$ in distilled water. Sodium diethyldithiocarbamate trihydrate $\left(\mathrm{C}_{5} \mathrm{H}_{10} \mathrm{NNaS}_{2} \cdot 3 \mathrm{H}_{2} \mathrm{O}\right)$ (Merck) was used as a complexing agent. For elution experiments, hydrochloric acid (\%37) ( $\mathrm{HCl}$ (Merck), sulfuric acid (\%98) (H2SO4) (Merck), nitric acid (\%65) (HNO3) (Merck) and ammonium carbonate $\left(\left(\mathrm{NH}_{4}\right)_{2} \mathrm{CO}_{3}\right)(\mathrm{RDH})$ were used. $\mathrm{NaOH}$ and $\mathrm{HCl}$ were used for $\mathrm{pH}$ adjustment.

\section{Preparation of IPNs}

For the preparation of IPNs, the solution of poly(ethylene glycol)(PEG35000MW) (1 g) in acrylonitrile(AN) (3 ml) irradiated to two different doses, 14 (14 IPN) and 60kGy (60 IPN), with 60Co- $\gamma$ radiation source $(5.0 \mathrm{kGy} . \mathrm{h}-1$ radiation dose rate) at room temperature. The actual irradiation reaction is given in Figure 1 . These IPNs were washed into $\mathrm{N}, \mathrm{N}$-dimethylformamide (DMF) for $24 \mathrm{~h}$ and were dried at $40 \circ \mathrm{C}$ to constant mass. The IPNs having a conversion ratio of $60 \%$ (14 IPNs) and 70\% (60 IPNs) were cut in a cylindrical shape $(3 \mathrm{~mm}$ diameter and $3 \mathrm{~mm}$ height) and prepared for use in the amidoximation reaction [1].

\section{Amidoximation of IPNs}

The cyano(CN) groups of 14 and 60 IPN were changed into an amidoxime ( $\mathrm{HONCNH} 2)$ group by reacting with hydroxylamine $(\mathrm{NH} 2 \mathrm{OH})$ solution at a molar ratio of $\mathrm{NH} 2 \mathrm{OH} / \mathrm{CN}=1.5$ in aqueous media at $70 \circ \mathrm{C}$ and $\mathrm{pH}=7$

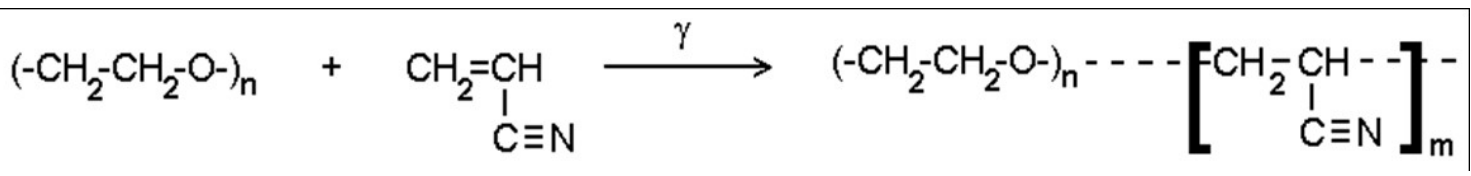

Figure 1. Irradiation reaction to obtain IPN from polyethylene glycol and acrylonitrile. 


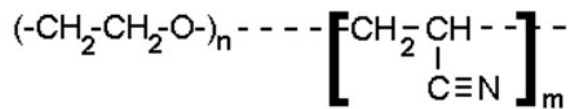

Figure 2. Amidoximation reaction of IPNs.

by 2 hours and amidoximated IPNs were obtained (14A and 60A IPNs). The reaction is shown in Figure 2. The amidoximated IPNs were washed with distilled-deionized water for $24 \mathrm{hrs}$ and then dried to constant mass at 40 으 [1].

\section{The Effect of $\mathbf{p H}$ on the Adsorption of $\mathrm{Ni}^{2+}$}

$14 \mathrm{~A}$ and $60 \mathrm{~A}$ IPNs (20 mg) were put into $10 \mathrm{ml} 50 \mathrm{ppm}$ $\mathrm{Ni}^{2+}$ solution at room temperature for $24 \mathrm{hrs}$. The solution $\mathrm{pH}$ was adjusted with $\mathrm{NaOH}$ and $\mathrm{HCl}$ as 2, 4, 6, 8 and 10. The concentration of $\mathrm{Ni}^{2+}$ ions in the solution was determined using UV-Vis spectrometer.

\section{The Effect of $\mathrm{mNi} / \mathrm{mIPN}$ Ratio on the Adsorption of $\mathrm{Ni}^{2+}$}

14A and 60A IPNs were put into $5 \mathrm{ml}$ of $100 \mathrm{ppm} \mathrm{Ni}^{2+}$ solution at $\mathrm{pH}=8$ and room temperature for $24 \mathrm{hrs}$ Samples with $\mathrm{mNi} / \mathrm{mIPN}$ ratios ranging from 0.002 to 0.5 were prepared. The concentration of $\mathrm{Ni}^{2+}$ ions in the solution was determined using UV-Vis spectrometer.

\section{The Effect of Flow Rate on the Adsorption of $\mathrm{Ni}^{2+}$}

$14 \mathrm{~A}$ IPNs (10 mg) were used in $100 \mathrm{ml}$ and 100ppm $\mathrm{Ni}^{2+}$ stock solution at flow rates of 3 and $6 \mathrm{ml} / \mathrm{s}$ at room temperature. Fiber glass (20 mg) was used as a filling material for the fixed-bed reactor in the reflux flow process. To ensure the continuous flow in the process, the Velp Scientifica Type SP311 model peristaltic pump was used.

\section{The Adsorption of $\mathrm{Ni}^{2+}$ in Batch and Flow Systems}

In the batch system, for investigation of $\mathrm{Ni}^{2+}$ ions adsorp- tion, 14A and 60A IPNs (20mg) were added into a tube containing $10 \mathrm{ml} \mathrm{Ni}{ }^{2+}$ solutions at a known concentration for $24 \mathrm{hrs}$ at room temperature. Experiments occurred at an optimum $\mathrm{mNi} / \mathrm{mIPN}$ ratio of 0.4 and two different $\mathrm{pH}$ values (seawater $\mathrm{pH}^{8}$ and solution $\mathrm{pH}^{6}$ ).

In the flow system, for investigation of $\mathrm{Ni}^{2+}$ ions adsorption, 14A and 60A IPNs (10mg) were used in reflux flow process with a fixed-bed reactor at room temperature, the optimum flow rate as $6 \mathrm{~mL} / \mathrm{s}$ and optimum $\mathrm{pH}$ value determined as 8 . The reservoir volume of the flow system was $100 \mathrm{ml}$.

The $\mathrm{pH}$ was adjusted to 8 with $\mathrm{NaOH}$. $\mathrm{Ni}^{2+}$ solutions were prepared by diluting 1000ppm stock solution of $\mathrm{Ni}^{2+}$, obtained by dissolving nickel (II) nitrate hexahydrate in distilled-deionized water. For the determination of adsorption, concentrations of $\mathrm{Ni}^{2+}$ were varied between 20-1000 ppm for the batch system and 25-400 ppm for the flow system. The concentration of $\mathrm{Ni}^{2+}$ ions in the solution was determined using by UV-Vis spectrometer.

\section{The Elution of $\mathrm{Ni}^{2+}$ in Batch Systems}

Adsorption of nickel ions on 14A and 60A IPNs (5mg) was performed in $20 \mathrm{ml} 100 \mathrm{ppm} \mathrm{Ni}{ }^{2+}$ solution for 24 hours at an optimum $\mathrm{mNi} / \mathrm{mIPN}$ ratio of 0.4 and $\mathrm{pH}=$ 8. IPNs were washed into distilled-deionized water for $24 \mathrm{hrs}$ and then dried to constant mass at $40 \circ \mathrm{C}$.

The 14A and 60A IPNs dried after the nickel adsorption were eluted with selected eluents (Table 1). For elution experiments, the eluent concentration was $1 \mathrm{M}$ and the

Table 1. The post-processing IPN codes.

\begin{tabular}{|c|c|c|c|c|}
\hline \multicolumn{3}{|c|}{ Process } & \multicolumn{2}{|c|}{ Code } \\
\hline Irradiation & Amidoximation & Eluent & $14 k G y$ & $60 \mathrm{kGy}$ \\
\hline Done & - & - & 14 & 60 \\
\hline Done & Done & - & $14 \mathrm{~A}$ & $60 \mathrm{~A}$ \\
\hline Done & Done & $\mathrm{HCl}$ & $14 \mathrm{AH}$ & $60 \mathrm{AH}$ \\
\hline Done & Done & $\mathrm{H}^{2} \mathrm{SO}^{4}$ & $14 \mathrm{AHS}$ & 60AHS \\
\hline Done & Done & $\mathrm{HNO}^{3}$ & $14 \mathrm{AHN}$ & 60AHN \\
\hline Done & Done & $\left(\mathrm{NH}^{4}\right)^{2} \mathrm{CO}^{3}$ & $14 \mathrm{ANC}$ & 6OANC \\
\hline Done & Done & $\mathrm{NaOH}$ & 14ANa & 60ANa \\
\hline
\end{tabular}




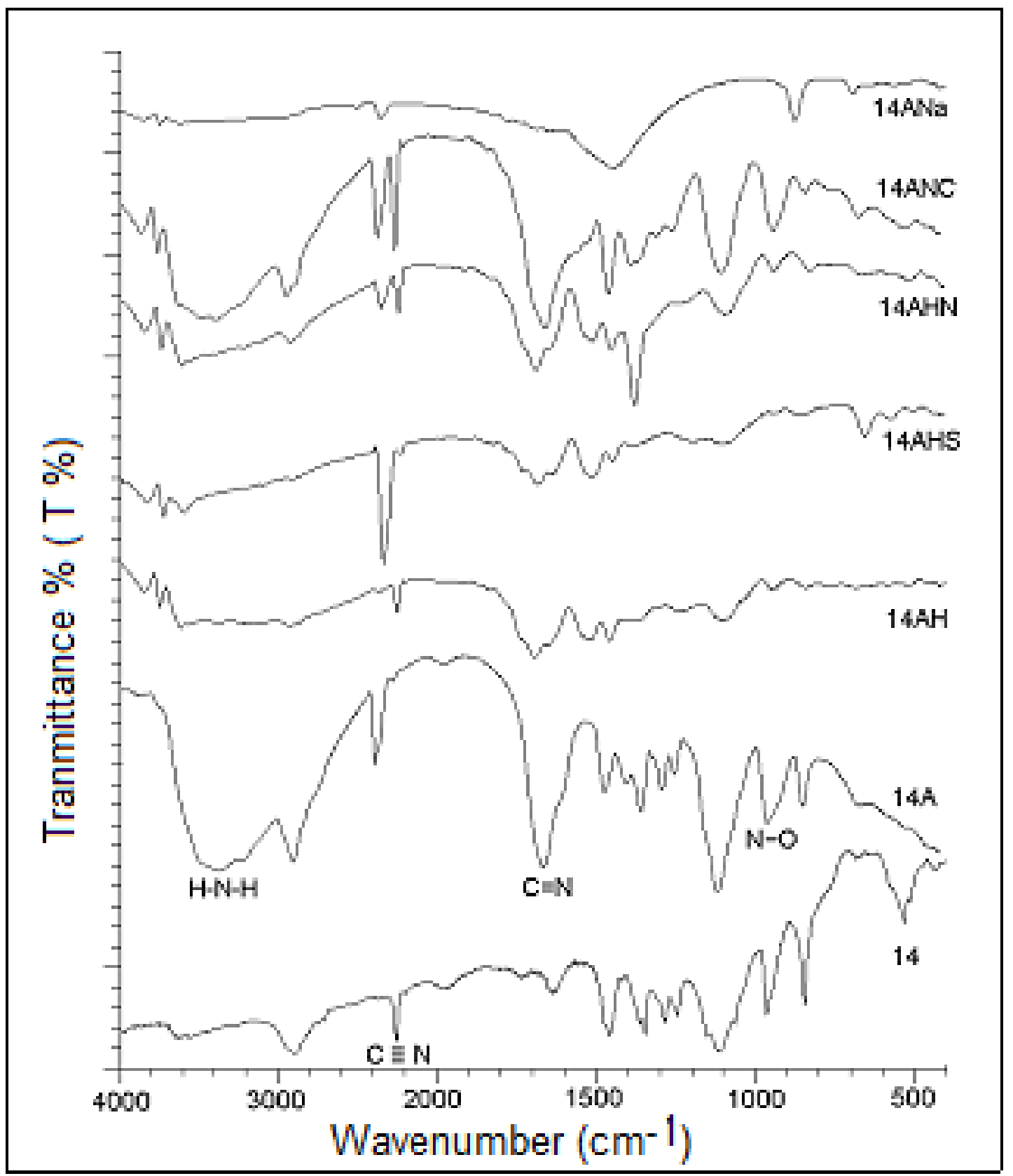

Figure 3. FTIR spectra of the IPNs irradiated to 14kGy dose (14), amidoximated (14A) and eluted after adsorption (14AH, 14AHS, 14AHN, $14 \mathrm{ANC}$ and $14 \mathrm{ANa}$ ).

elution volume was $10 \mathrm{ml}$. The codes of the IPNs after elution are given in Table 1 . The concentration of $\mathrm{Ni}^{2+}$ ions in eluent solution were determined using on UV-Vis spectrometer. Eluted IPNs structures were determined with FTIR spectrophotometer.

\section{Determination of $\mathrm{Ni}^{2+}$ Concentration and} Characterization of IPNs

After adsorption and elution, the equilibrium concentration of $\mathrm{Ni}^{2+}$ ions in solution was determined using UV-Vis spectrometer (Shimadzu UV1201V model) at $426 \mathrm{~nm}$ with sodium diethyl-dithiocarbamate as a complexing agent $(\mathrm{pH}=4)$. The percent of $\mathrm{Ni}^{2+}$ eluted from IPN (Elution efficiency, E, \%) and the amount of $\mathrm{Ni}^{2+}$ adsorbed were determined by Eqn. 1 and 2, respectively:
$\mathrm{E}=100 \times\left(\left(\mathrm{C}_{0}-\mathrm{C}_{\mathrm{e}}\right) / \mathrm{C}_{0}\right)$
Eqn. 1
$\mathrm{Q}=\left(\left(\mathrm{C}_{0}-\mathrm{C}_{\mathrm{e}}\right) \times \mathrm{V} / \mathrm{M}\right)$
Eqn. 2 
where $\mathrm{C}_{0}$ and $\mathrm{C}_{\mathrm{e}}$ are the initial and equilibrium concentrations of $\mathrm{Ni}^{2+}$ ions $(\mathrm{mg} / \mathrm{L}), \mathrm{M}$ is the mass of adsorbent $(\mathrm{g}), \mathrm{V}$ is the volume of sample $(\mathrm{L})$, and $\mathrm{Q}$ is the amount of $\mathrm{Ni}^{2+}$ ions adsorbed per mass of adsorbent (mg/g) [14].

After irradiation, amidoximation and elution, the change in the structure of the IPNs was determined using FTIR spectrophotometer (Shimadzu FTIR 8300) at between 400-4000 $\mathrm{cm}^{-1}$ intervals.

\section{RESULTS and DISCUSSION}

\section{Characterisation of IPNs}

14 and 60 IPNs obtained in white colour and homogeneously have a hard structure. Their hardness was increased with increasing radiation dose due to crosslinking. In the FTIR spectra of PEG-AN irradiated to 14 and 60kGy doses, the peak of nitrile $(C \equiv N)$ group at $2242 \mathrm{~cm}^{-1}$, which is the characteristic stretching band of nitrile and the peak strength, was increased with increasing radiation dose due to conversion (\%). The peak of $1100 \mathrm{~cm}^{-1}$ and symmetric peaks in its two sides is called fingerprint zone and corresponding to $\left[-\mathrm{CH}_{2}-\mathrm{CH}_{2}-\right]$ structure in the chain (Figure 3 and 4, 14 and 60 spectra). End of this reaction, IPNs have no functional group (amidoxime group) and do not chelate with metal ions but could be adsorbed only by swelling [1].

In the FTIR spectrum of $14 \mathrm{~A}$ and 60A IPNs, appeared $\mathrm{H}-\mathrm{N}-\mathrm{H}$ $\left(3360-3390 \mathrm{~cm}^{-1}\right), \mathrm{N}-\mathrm{O}\left(940 \mathrm{~cm}^{-1}\right), \mathrm{C}=\mathrm{N}\left(1652 \mathrm{~cm}^{-1}\right)$ peaks and disappeared $\mathrm{C} \equiv \mathrm{N}\left(2242 \mathrm{~cm}^{-1}\right)$ peak show that the cya-

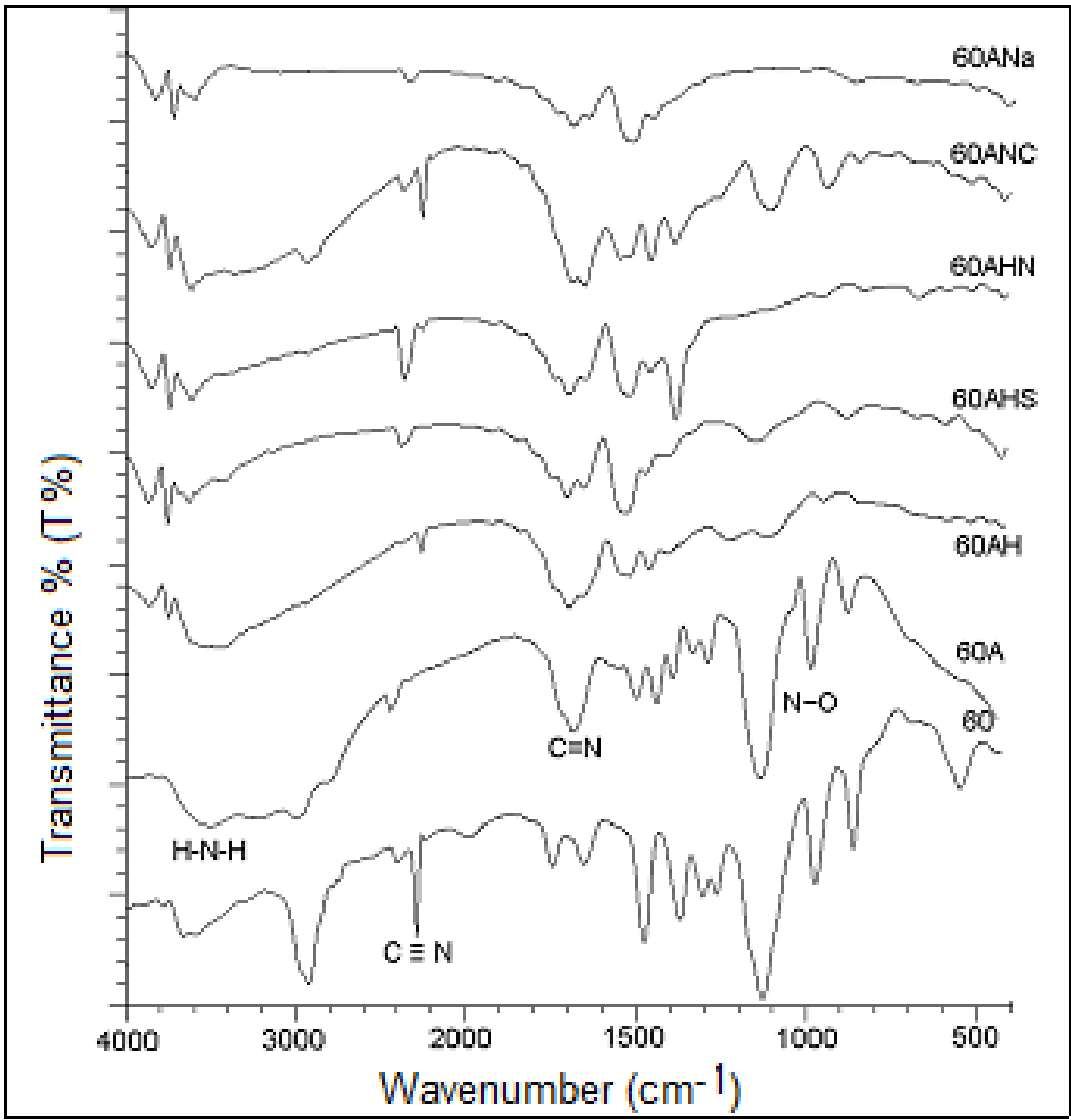

Figure 4. FTIR spectra of the IPNs irradiated to 60kGy dose (60), amidoximated (60A) and eluted after adsorption (60AH, 60AHS, 60AHN, 60ANC and 60ANa). 


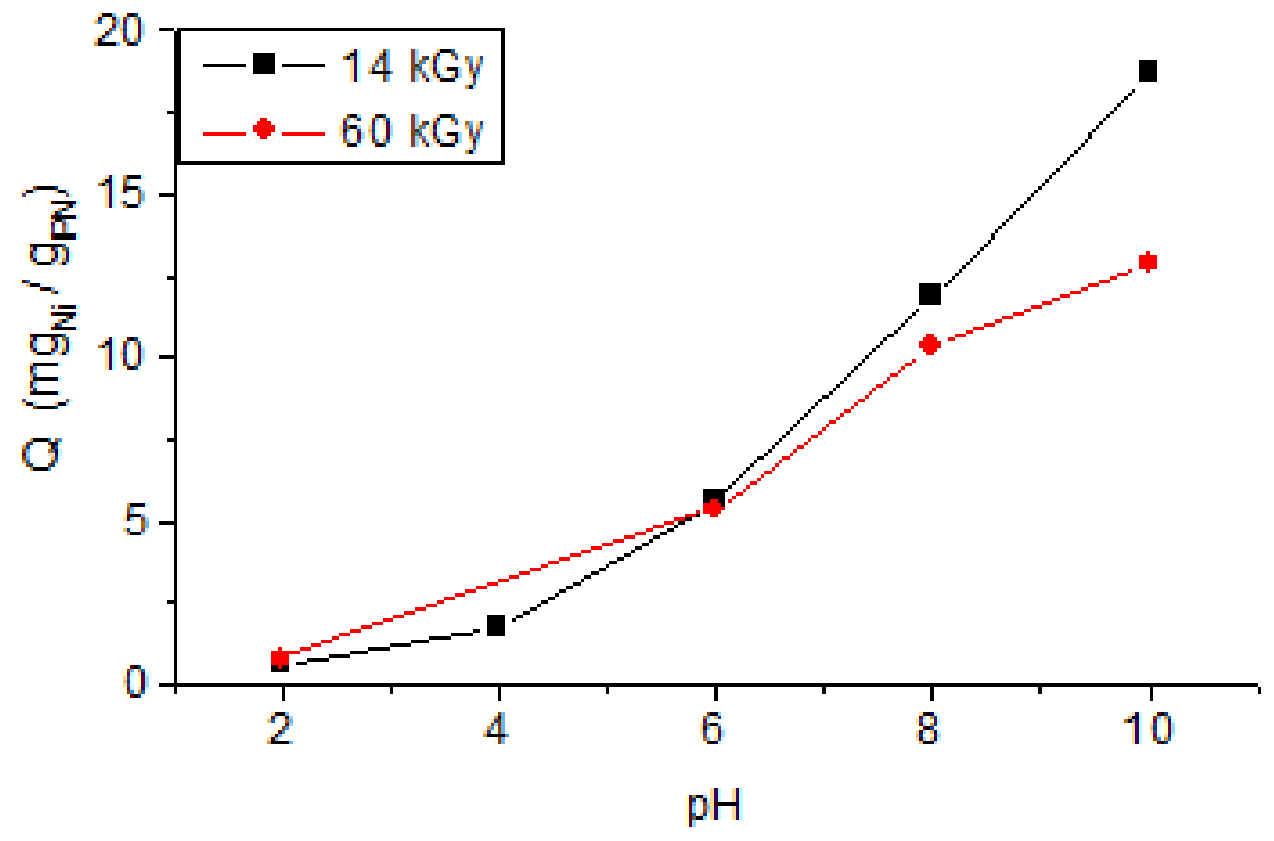

Figure 5. The effect of $\mathrm{pH}$ on the adsorption of $\mathrm{Ni} 2+$ ions $(\mathrm{CO}=100 \mathrm{ppm}$, room temperature and batch system).

no group of IPNs was changed into amidoxime group by reacting with hydroxilamine in both radiation dose (Figure 3 and $4,14 \mathrm{~A}$ and $60 \mathrm{~A}$ spectra). The peak strength of $\mathrm{C}=\mathrm{N}$ in $14 \mathrm{~A}$ spectrum is more than in $60 \mathrm{~A}$ spectra. This result shows that the amidoxime group in 14A IPNs was formed more in 60A IPNs and amidoximation was decreased with increasing radiation dose. After the amidoximation reaction, the IPNs have both amidoxime functional groups for chelating with heavy metal ions and hydrophilic groups providing swelling in aqueous media [1].

Five post-elution samples of IPNs irradiated to a dose of $14 \mathrm{kG}$ are seen in the comparative FTIR spectrum, and all of these eluted IPN constructs are partially degraded, except for 14ANC (Figure 3 and Table 1). In the 14AH and 14AHN spectra, $C \equiv N$ peaks indicated that the structure of IPNs returned before amidoximation. 14ANa spectrum shows that the chain structure is degraded due to disappearing $C \equiv N$ peak and fingerprint zone. The comparative FTIR spectra of irradiated to $60 \mathrm{kGy}$ dose seven IPNs samples is shown in Figure 4 and sample codes are given Table $1 . \mathrm{NH}_{2}, \mathrm{NO}$ and $\mathrm{C}=\mathrm{N}$ peaks in all spectra correspond to amidoxime structure. $\mathrm{NH}_{2}$ and $\mathrm{C}=\mathrm{N}$ peaks were obtained in $60 \mathrm{ANC}$ and $60 \mathrm{AH}$
IPNs spectra but peak strengths decreased. NO peak was obtained only in 60ANC sample spectra but peak strength decreased. As seen from the FTIR spectra, these changes in peaks show changes in IPN structures after elution.

For both doses (14 and 60kGy), the elution efficiency of $\mathrm{HCl}$ as the eluent was the maximum, but the amidoxime group in the IPN structure was degraded according to the FTIR spectrum. Although $\left(\mathrm{NH}_{4}\right)_{2} \mathrm{CO}_{3}$ as the eluent had the lowest elution yield, minimal structural degradation of IPNs occurred.

\section{The Effect of $\mathrm{pH}$ on the Adsorption of $\mathrm{Ni}^{2+}$}

For the adsorption of $\mathrm{Ni}^{2+}$ ions with irradiated and amidoximated IPNs (14A and 60A), adsorption medium $\mathrm{pH}$ was changed from 2 to 10 . This $\mathrm{pH}$ range was selected due to the hydrolysis reaction possibility of the nickel ions out of this range. As a result of the experiments, the adsorption of $\mathrm{Ni}^{2+}$ ions with irradiated and amidoximated IPNs (14A and 60A) was increased with rising $\mathrm{pH}$. For both doses irradiated IPNs minimum and maximum adsorption values were obtained at $\mathrm{pH}=2$ and $\mathrm{pH}=10$, respectively. Due to the decomposition of IPNs 


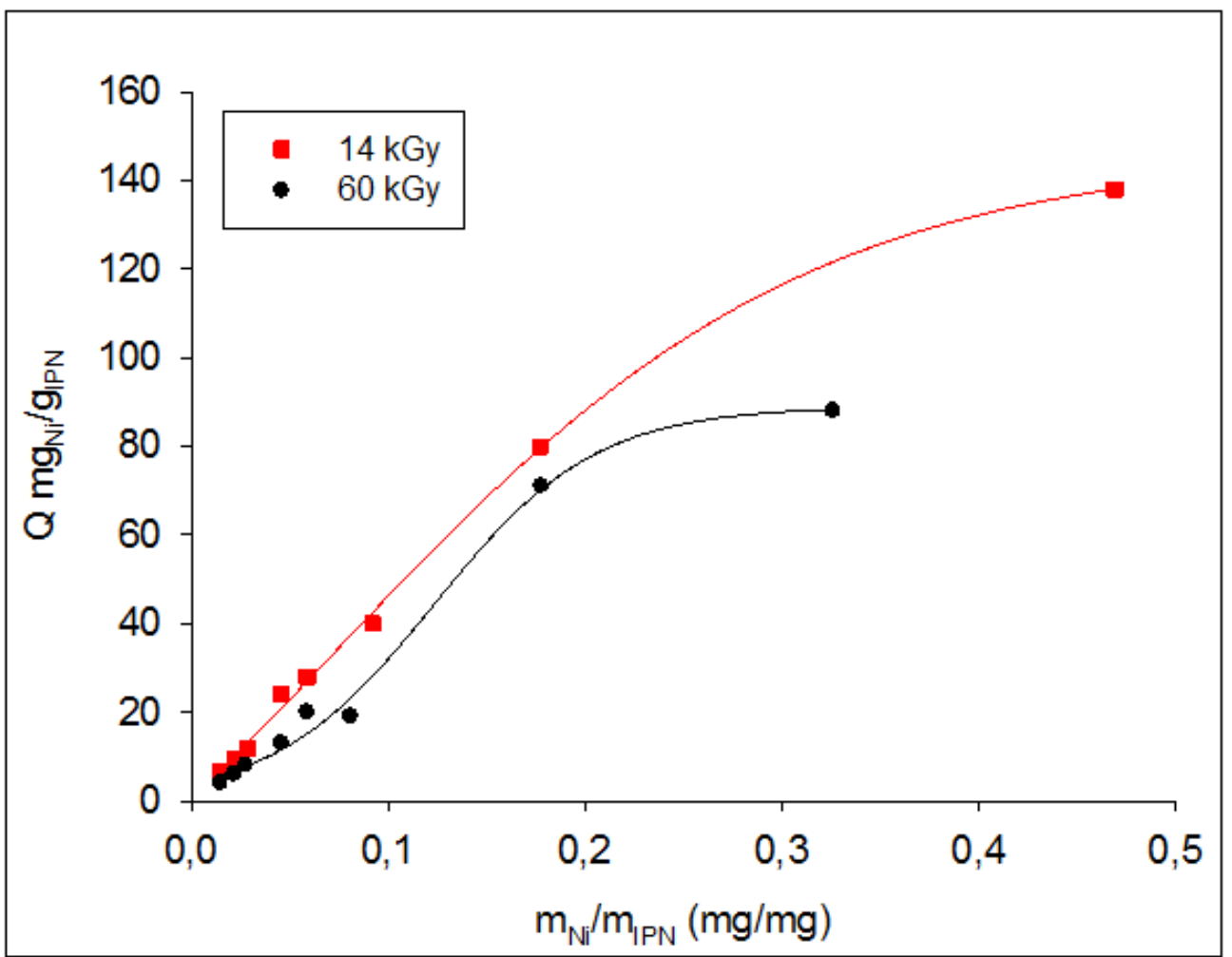

Figure 6. The effect of $\mathrm{mNi} / \mathrm{mIPN}$ ratio on the adsorption of $\mathrm{Ni}^{2+}$ ions $(\mathrm{CO}=100 \mathrm{ppm}, \mathrm{pH}=8$, room temperature and batch system).

at $\mathrm{pH}=10$, the optimum $\mathrm{pH}$ was selected as 8 for further experiments (Figure 5). It was reported in the related literature that the $\mathrm{pH}$ of the adsorption medium is one of the most important parameters affecting the adsorption capacities $[2,4,13]$. Adsorption values of amidoxime group-containing adsorbents synthesized by radiation-based vaccination for nickel ions were investigated between $\mathrm{pH} 2$ and 6 and the most suitable $\mathrm{pH}$ was determined to be 6 [2]. In another study, poly (ethylene terephthalate) fibres grafted with methacrylic acid for the $\mathrm{pH}$ effect on the nickel adsorption was carried out from 2 to 10 and 6 was selected as the optimum $\mathrm{pH}$ [4]. For the nickel ions adsorption onto the PEGMA-VI microspheres, adsorption medium $\mathrm{pH}$ was changed from 2 to 8 and high adsorption capacities were observed above $\mathrm{pH} 6$ [13].

\section{The Effect of $\mathrm{m}_{\mathrm{Ni}} / \mathrm{m}_{\mathrm{IPN}}$ Ratio on the Adsorption of $\mathrm{Ni}^{2+}$} The relationship between $m_{N i} / m_{I P N}$ ratio and nickel ion adsorption of IPNs (14A and 60A) is given in Figure 6.
The optimum $m_{N} / m_{I P N}$ ratio for $14 \mathrm{~A}$ and $60 \mathrm{~A}$ IPNs was determined to be 0.4 . At this ratio, the adsorption of $\mathrm{Ni}^{2+}$ ions with 14A IPNs was 1.5 times more than with $60 \mathrm{~A}$ IPNs. This is thought to be due to the cross-linking ratio. Due to the low irradiation dose, the crosslinking ratio in 14A IPNs is lower than that found in 60A IPNs. Thus, 14A IPNs were more swollen and were able to adsorb more nickel ions than 60A IPNs (Figure 6). The change of the water content of the IPNs with the irradiation was reported in the related literature [1].

\section{The Effect of Flow Rate on the Adsorption of $\mathbf{~ N i}^{2+}$}

The effect of flow rate on nickel ion adsorption in the continuous system was realized with 14A IPNs and the results are given in Figure 7 . The adsorbed $\mathrm{Ni}^{2+}$ ions increased with time in the IPN structure and the steadystate was reached after 40 minutes due to the filling of the active sites in the IPN. The adsorption of $\mathrm{Ni}^{2+}$ ions with $14 \mathrm{~A} I P N$ at a flow rate $6 \mathrm{ml} / \mathrm{s}$ was 1.25 times higher at $3 \mathrm{ml} / \mathrm{s}$. Thus, the optimal flow rate is determined to be $6 \mathrm{ml} / \mathrm{s}$ (Figure 7). In the related literature, some 


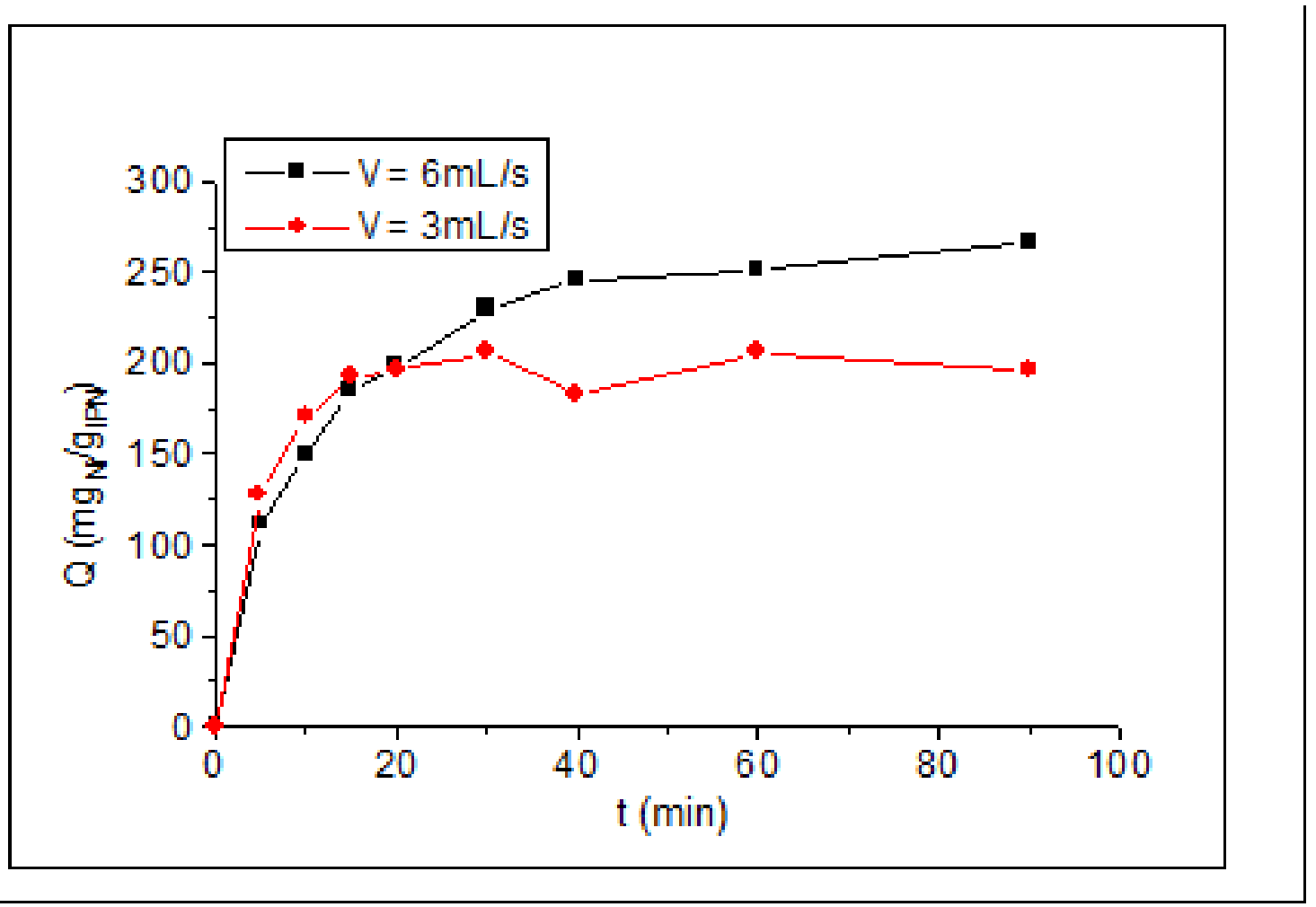

Figure 7. The effect of flow rate on the adsorption of $\mathrm{Ni}^{2+}$ ions $(\mathrm{CO}=100 \mathrm{ppm}, \mathrm{pH}=8$, room temperature and flow system).

adsorbents have been reported to reach a steady-state [11-13]. The time to reach a steady-state in nickel ion adsorption was determined as 60 minutes in P[AAm/ DAPB/DAMB] hydrogel [11], 40 minutes in polyethyleneimine (PEI)-attached poly(p-chloromethyl styrene) (PCMS) beads [12], 120 minutes in PEGMA-VI microspheres [13].

\section{The Adsorption of $\mathrm{Ni}^{2+}$ at the Optimum Conditions}

The adsorption isotherms for the $14 \mathrm{~A}$ and 60A IPNs in batch ( $\mathrm{pH}=6$ and 8$)$ and flow $(\mathrm{pH}=8)$ systems are shown in Figure 8. According to Gile's isotherms, the adsorption isotherms for $14 \mathrm{~A}$ and $60 \mathrm{~A}$ IPNs in batch system at $\mathrm{pH}=6$ and 8 were fixed as $\mathrm{S} 2$ type; in flow system at $\mathrm{pH}=8$ were fixed as L2 type and the correlation coefficients for Langmuir isotherms were determined as 0.96 and 0.95; for Freundlich isotherms were determined as 0.99 and 0.98 , respectively. Similar results have been obtained in the studies in the related literature $[14,15,21]$.

For each adsorption systems (batch; $\mathrm{pH}=6$ and $\mathrm{pH}=8$ and flow; $\mathrm{pH}=8$ ), the adsorption of $\mathrm{Ni}^{2+}$ ions with $14 \mathrm{~A}$ IPNs is greater than with 60A IPNs (Figure 8 and Table 2). This is thought to be due to the cross-linking ratio. Because of the increased radiation dose, the cross-linking rate in the
IPN structure is increased and therefore the swelling of the IPNs is reduced and the adsorption of $\mathrm{Ni}^{2+}$ ions is reduced accordingly. For the IPNs 14A and 60A in batch ( $\mathrm{pH}=6$ and 8) and flow $(\mathrm{pH}=8)$ systems maximum adsorption value was obtained at $\mathrm{pH}=8$ (Figure 8 and Table 2). This may be due to non-amidoxime nitrile groups in the IPN structure. In the IPNs, the non-amidoximatated nitrile group is hydrolysed and then the $\mathrm{pH}$ of the medium is increased to the carboxylic acid group. Meanwhile, the increase in the hydrophilic group in the structure causes the swelling of the IPNs and the adsorption of $\mathrm{Ni}^{2+}$ ions increases. Adsorption values for $14 \mathrm{~A}$ and $60 \mathrm{~A}$ IPNs in batch $(\mathrm{pH}=6$ and 8$)$ and flow $(\mathrm{pH}=$ 8) systems were the highest values obtained in the flow system (Figure 8 and Table 2). This is considered to be an increase in the diffusion effect resulting from the flow rate. The solution and adsorbate in the flow system make more contact, and the flow causes a mixing effect similar to that in the batch system. This effect increases the diffusion rate and adsorption of $\mathrm{Ni}^{2+}$ ions. The highest adsorption values in the IPNs prepared for nickel adsorption reached in the flow system with 14A IPNs. For these 14A IPNs, the maximum adsorption value was obtained above $96 \%$ with a maximum adsorption capacity of about $900 \mathrm{mg}_{\mathrm{Ni}} / \mathrm{g}_{\text {IPN }}$ at $\mathrm{pH}$ $=8$ (Figure 8 and Table 2). 


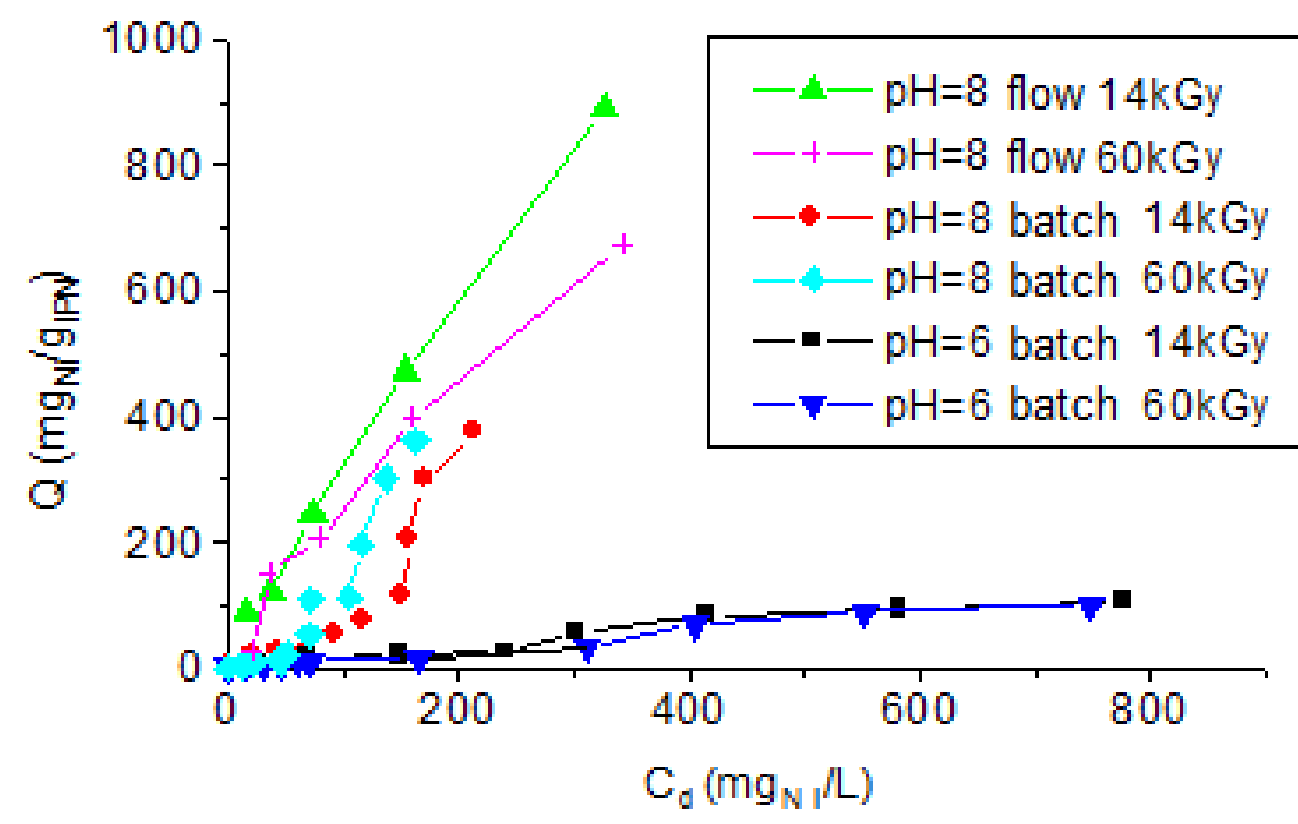

Figure 8. For radiated to 14 and $60 \mathrm{kGy}$ doses and amidoximated IPNs, the adsorption isotherms in batch ( $\mathrm{pH}=6$ and 8) and flow $(\mathrm{pH}=8)$ systems.

In the comparison of the obtained results with the related literature, it is also possible to find some polymeric adsorbents for the adsorption of nickel. The adsorption capacities of amidoxime-group-containing adsorbents synthesized by radiation-induced and poly(ethylene terephthalate) fibres grafted with methacrylic acid, were found as $29 \mathrm{mg} / \mathrm{g}$ [2] and $456 \mathrm{mg} / \mathrm{g}$ [4] for nickel ions, respectively. Nickel adsorption is more than $98 \%$ in the process of removing and recovering nickel ions with a chelating resin containing triethylenetetramine in the flow system [7]. The adsorption capacity of nickel ions from aqueous solutions by Poly[acrylamide/N,N-DAMB/N,N-DAPB] super absorbent hydrogel in batch system is determined as $95 \mathrm{mg} / \mathrm{g}$ [12]. The nickel adsorption value by PEGMA-VI microparticles reached $78 \mathrm{mg} / \mathrm{g}$ as maximum rate at $\mathrm{pH} 6$ [13].

\section{The Elution of IPNs}

At the end of the adsorption studies, IPNs were eluted with various eluents to recover nickel from IPNs. The elution efficiency and eluent type obtained for the irradiated to 14 and 60kGy doses and amidoximated IPNs (14A and 60A) are given in Table 3. According to the data in the table, the maximum elution efficiency was obtained with $\mathrm{HCl}$ used as the eluent. For $14 \mathrm{AH}$ and 60AH IPNs, the elution efficiency of $\mathrm{HCl}$ was $99.46 \%$ and $66.06 \%$, respectively. The minimum elution efficiency was observed with $\left(\mathrm{NH}_{4}\right)_{2} \mathrm{CO}_{3}$ used as the eluent. For 14ANC and 60ANC IPNs, the elution efficiency of $\left(\mathrm{NH}_{4}\right)_{2} \mathrm{CO}_{3}$ is $60.05 \%$ and $58.18 \%$, respectively. As can be seen from Table 3 , the elution efficiency values of $14 \mathrm{~A}$ IPNs adsorbed nickel ions are greater than the values

Table 2. Maximum adsorption values for irradiated to 14 and 60kGy doses IPNs in batch ( $\mathrm{pH}=6$ and 8 ) and flow ( $\mathrm{pH}=8)$ systems.

\begin{tabular}{ccccc}
\hline System & PH & & Q (mgNi/gIPN) & \\
\hline & & $14 k G y$ & $60 k G y$ & 99 \\
\hline Batch & 6 & 378 & 361 \\
\hline Batch & 8 & 891 & 673 \\
\hline
\end{tabular}


Table 3. Elution efficiency of IPNs irradiated to 14 and 60kGy doses (\% E).

\begin{tabular}{ccc}
\hline Eluent type & 14 kGy E\% & $60 k$ ky E\% \\
\hline $\mathrm{HCl}$ & 99.46 & 66.06 \\
\hline $\mathrm{H}_{2} \mathrm{SO}_{4}$ & 92.24 & 63.16 \\
\hline $\mathrm{HNO}_{3}$ & 83.02 & 58.03 \\
\hline$(\mathrm{NH} 4)_{2} \mathrm{CO}_{3}$ & 60.05 & 58.18 \\
\hline $\mathrm{NaOH}$ & 71.22 & 48.53 \\
\hline
\end{tabular}

obtained at 60A IPN. This is thought to result from the increased cross-linking with increasing radiation dose. Crosslinking in the IPN structure causes less swelling, resulting in a reduction in desorption of nickel.

It is also possible to find some polymeric adsorbents for the nickel desorption in comparison with the literature. The desorption capacity of poly(ethylene terephthalate) fibres grafted with methacrylic acid was found as $96.5 \%$ [4]. Nickel desorption is more than $99 \%$ in the process of removing and recovering nickel ions with a chelating resin containing triethylenetetramine [7]. The desorption capacity of poly[acrylamide/N,N-DAMB/N,N-DAPB] super absorbent hydrogel in batch system is determined as $85 \%$ [12]. The desorption efficiency of PEGMA-VI microparticles reached 99\% [13].

\section{Conclusion}

As a result, IPNs irradiated to $14 \mathrm{kGy}$ and optimally amidoximated to recover or remove $\mathrm{Ni}^{2+}$ ions should be used at $\mathrm{pH}=8$ and in the flow system. By the way, maximum adsorption efficiency (\%96.2) is reached. In addition to all the adsorbents developed so far, the main feature of amidoximated IPNs used in this study is that it can adsorb $\mathrm{Ni}^{2+}$ ions at low concentrations as well as high concentrations. This study indicates that amidoximated IPNs can be efficiently used as wastewater $\mathrm{pH}$ values between $\mathrm{pH}=6$ and 8 . However, the nickel adsorption at $\mathrm{pH}=8$ is twice as much as the adsorption at $\mathrm{pH}=6$. In this respect, IPNs are also suitable for $\mathrm{Ni}^{2+}$ recovery from seawater with a $\mathrm{pH}$ of 8.3 .

In addition to this the eluent, which prefers to use in the industry, must be obtained by processing condition. Where high desorption efficiency is desired, $\mathrm{HCl}$ may be selected as the eluent. Given the adsorbent cost, $\left(\mathrm{NH}_{4}\right)_{2} \mathrm{CO}_{3}$ can be selected as an optimum eluent. The adsorbents obtained in this study can be used as adsorbents for the recovery and removal of nickel from aqueous media.

\section{References}

1. H. Güler, N. Şahiner, G.A. Ayçık, O. Güven, Development of novel adsorbent materials for recovery and enrichment of uranium from aqueous media, J. Appl. Polym. Sci., 66 (1997) 2475-2480.

2. J. Okamoto, T. Sugo, A. Katakai, H. Omichi, Amidoxime-groupcontaining adsorbents for metal ions synthesized by radiationinduced grafting, J. Appl. Polym. Sci., 30 (1985) 2967-2977.

3. L. Astheimer, H.J. Schenk, E.G. Witte, K. Schwochau, Development of sorbers for the recovery of uranium from seawater. Part 2. The accumulation of uranium from seawater by resins containing amidoxime and ımidoxime functional groups, Separ. Sci. Technol., 18 (1983) 307-339.

4. H. Bag, A.R. Turker, R. Coskun, M. Sacak, M.Yigitoglu, Determination of zinc, cadmium, cobalt and nikel by flame atomic absorption spectrometry after preconcentration by poly(ethylene terephthalate) fibers grafted with methacrylic acid, Spectrochimica Acta B, 55 (2000) 1101-1108

5. H. Egawa, T. Nanaka, M. Nakayama, Influence of crosslinking and porosity on the uranium adsorption of macroreticular chelating resin containing amidoxime groups, J. Macromol. Sci. Chem. A, 25 (1988) 1407-1425.

6. H. Karpinnen, A. Ylipentti, Evaluation of selective ion exchange for nickel and cadmium uptake from the rinsewaters of a plating shop, Separ. Sci. Technol., 35 (2000) 1619-1633.

7. H. Maeda, H. Egawa, Removal and recovery of nickel ion in sodium citrate solution with chelating resin containing triethylenetetramine side chain, J. Appl. Polym. Sc., 45 (1992) 173176.

8. H. Omichi, A. Katakai, T. Sugo, J. Okamoto, A new type of amidoxime-group-containing adsorbent for the recovery of uranium from seawater, Separ. Sci. Technol., 20 (1985) 163-178.

9. H. Omichi, A. Katakai, T. Sugo, J. Okamoto, A new type of amidoxime-group-containing adsorbent for the recovery of uranium from seawater. III. Recycle use of adsorbent, Separ. Sci. Technol., 21 (1986) 563-574.

10. H.J. Schenk, L. Astheimer, E.G. Witte, K. Schwochau, Development of sorbers for the recovery of uranium from seawater. 1. Assessment of key parameters and screening studies of sorber materials, Separ. Sci. and Technol., 17 (1982) 1293-1308.

11. A.M. Patel, R.G. Patel, M.P. Patel, Nickel and copper removal study from aqueous solution using new cationic Poly[acrylamide/N,NDAMB/N,N-DAPB] super absorbent hydrogel, J. Appl. Polym. Sci., 119 (2011) 2485-2493.

12. R. Say, A. Tuncel, A. Denizli, Adsorption of $\mathrm{Ni}^{2+}$ from aqueous solutions by novel polyethyleneimine-attached poly(pchloromethylstyrene) beads, J. Appl. Polym. Sci., 83 (2002) 2467-2473 
13. E. Uguzdogan, E.B. Denkbas, O.S. Kabasakal, The use of polyethyleneglycolmethacrylate-co-vinylimidazole (PEGMA-co-VI) microspheres for the removal of nickel(II) and chromium(VI) ions, J. Hazar. Mater., 177 (2010) 119-125.

14. D. Türkmen, V. Karakoç, L. Uzun, N. Öztürk, S. Akgöl, A Denizli, Poly(hydroxyethyl methacrylate) Nanoparticles for Environmental Applications, Hacettepe J. Biol. Chem., 37 (2009) 157-168.

15. V. Gupta, Equilibrium uptake, sorption dynamics, process development, and column operations for the removal of copper and nickel from aqueous solution and wastewater using activated slag, a low-cost adsorbent, Ind. Eng. Chem. Res., 3 (1998) 192-202.

16. P. Ricou, I. Leayer, P. Leclairec, Influence of $\mathrm{pH}$ on Removal of heavy metallic cations by fly ash in aqueous solution, Environ. Technol., 19 (1998) 1005-1016.

17. S. Triantafyllou, E. Christodoulou, P.N. Syngouna, Removal of nickel and cobalt from aqueous solutions by na-activated bentonite, Clay Clay Miner., 47 (1999) 567-572.
18. C. Haktanır, Removal of Heavy Metals From Aqueus Solution Using Activated Carbon Embedded Cryogels, Hacettepe J. Biol. Chem., 45 (2017) 135-142

19. Z. Aksu, Ü. Açıkel, E. Kabasakal, S. Tezer, Equilibrium modelling of individual and simultaneous biosorption of chromium(VI) and nickel(II) onto dried activated sludge, Water Res., 36 (2002) 3063-3073.

20. S. Al-Asheh, F. Banat, F. Mohai, Sorption of copper and nickel by spent animal bones, Chemosphere, 39 (1999) 2087-2096.

21. I. Villaescusa, M. Martinez, N. Miralles, Heavy metal uptake from aqueous solution by cork and yohimbe bark wastes, J. Chem. Technol. Biotechnol., 75 (2000) 812-816. 